a. Ascending arm of Lockyer's curve.
1. Rigelian stars
$\mathrm{V}_{2}{ }^{0}=+2 \cdot 3 \mathrm{~km}$.
$=+8.8$,
3 stars
2. Taurian ,
$=+3.7$,
4 ,
3. Crucian,,
$3^{8}$,

B. Maximum of Lockyer's curve.
I. Alnitamian stars $\quad \mathrm{V}_{2}{ }^{0}=-0^{\circ} 4 \mathrm{~km}$.
5 stars
2. Argonian
o,

$\gamma$. Descending arm of Lockyer's curve.
I. Achernian star
$\mathrm{V}_{2}{ }^{0}=-5.4 \mathrm{~km}$.
I I stars
2. Algolian
$=-3.7$,
IO ,

Grouping them further, and taking general means for each of the groups $\alpha, \beta$, and $\gamma$, we get :-

$$
\begin{array}{lrrrr}
\text { a. } \mathrm{V}_{2}{ }^{0}=+4.1 \mathrm{~km} . & 45 \text { stars mean error } \pm \mathrm{I} \cdot 03 \mathrm{~km} . \\
\text { B. } \mathrm{V}_{2}^{0}=-0.4, & 5,, & , & \pm \mathrm{I} \cdot 29, \\
\gamma . \mathrm{V}_{2}{ }^{0}=-4.6, & 2 \mathrm{I}, & , & \pm \mathrm{I} \cdot 72,
\end{array}
$$

It is obvious that the $\beta$ group is so small, and its mean error so much greater than the mean value of the velocities, that it is negligible, and Dr. Ludendorff considers only the $\alpha$ and $\gamma$ groups; the difference between these is $+8.7 \mathrm{~km}$., with a mean error of $+2.0 \mathrm{~km}$.

Further analysis shows that, of the forty-five stars in group $\alpha$, thirty-one have $V_{2}$ positive, with a maximum of $+25 \mathrm{~km}$., and fourteen negative, with a maximum negative value $-7 \mathrm{~km}$., while the mean of the + values is $+7 \cdot 2$, and that of the negative values -2.8 .

Analysing similarly the $\gamma$ group, the mean $-V_{2}$ is $8.8 \mathrm{~km}$., and the mean $+\mathrm{V}_{2}$ is $+3.9 \mathrm{~km}$., so there can remain no reasonable doubt as to the reality of the connection between + values and " ascending" stars and - values and "descending" stars.

Taking these same seventy-one stars and arranging them under the Harvard equivalents of the Lockyer classes is rather a hazardous proceeding on account of the generical differences of the two classifications with their consequent overlappings; but Dr. Ludendorff has done it systematically, and finds that the mean velocity difference between the analogues of the $\alpha$ and $\gamma$ groups employed above is $+3.6 \mathrm{~km}$., with a probable error of $+2.4 \mathrm{k} \mathrm{km}$ It is evident that the systematic difference so obvious in the previous tables is somewhat obscured, and it becomes more so when the whole of Campbell's 224 stars are arranged under the Harvard equivalents of the Lockyer classes. Dr. Ludendorff therefore concludes the comparisons with the statement that when one arranges the helium stars of Campbell's catalogue under the Lockyer classification, there appears in the mean values of the absolute radial velocities of the several classes a distinct systematic difference. When one arranges the stars under the Harvard, or the Miss Maury, classifications, this systematic difference is not so clear as under the Lockyer arrangement.

Arising out of the question as to the reality of the observed difference, several suggestions as to its origin are made. The question of systematic error in the actual measuring is dismissed, and the evidence of streaming, disclosed by arranging the stars in four R.A. groups, is very small.

Dr. Ludendortt concludes with the suggestion that the wave-lengths in the spectra of helium stars vary with the condition of the star, and that this variation of condition may also be a function of Lockyer's arrangement of the stellar classes. Further, he makes the important suggestion that, as the Lockyer classification discloses this systematic difference, while the Harvard classifications do not show it so clearly, in the future discussion of a definite classification of the stars the classification which discloses this difference, possibly dependent upon spectral evolution, should receive most careful consideration. The elements of the spectral change, as shown in this discussion of the helium stars, are already incorporated in the classification, which by further natural development, and maybe slight modifications, may be made still more to portray the development of a star as it grows older.

William E. Rozston.

\section{EDUCATIONAL CONFERENCES CONSIDERED IN RELATION TO SCIENCE IN PUBLIC SCHOOLS.'}

\author{
II
}

Laboratory Work in Schools and in Examinations.

I $N$ our previous article we gave an account of those discussions at the annual meeting of the Public School Science Masters' Association which dealt with the sequence of studies. The remaining discussions were concerned with the position of qualitative analysis and the relation between laboratory work in schools and the practical examinations of public examining bodies. Dr. E. B. Ludlam (Clifton) found the position of the teacher difficult, as he thought that modern methods were better than those in which qualitative analysis had figured so largely, but was obliged by the scholarship examinations and those for the higher certificate to retain too much of the older methods. At the same time, he found that boys were stimulated by exercises in the identification of substances, a process which enlarged a boy's chemical experience and gave scope to his individuality. He therefore advocated a study of " comparative chemistry," with early attention to metals and the periodic classification; in connection therewith, the boys should work out their own methods of identification. From the discussion on examinations, opened by Mr. G. F. Daniell, it appeared that there was a desire for more alternative questions, i.e. more options, in the practical tests, and Mr. H. Richardson suggested a number of useful variants from the ordinary type of question. In practical chemistry, the use of the blow-pipe and some work with unknown substances should be retained; but there had been too much refinement of analytical work, both qualitative and volumetric. Problems, accompanied by fairly full working instructions, would bring the examination work more into line with the work in the school laboratory. The opener, and several subsequent speakers, advocated closer relations between teachers and examiners, and agreed that it was important that the examiner should be present during the laboratory examination.

\section{Mathematical Teaching.}

It is usually unprofitable to deal with papers on mathematical subjects by means of short abstracts. We therefore give the programme of the meeting of the Mathematical Association, and attempt to review the present position in the light of the discussions.

The president's address, by Prof. E. W. Hobson, appeared in NaTURe of January 18. Mr. C. Godfrey gave some account of the work of the International Commission on Mathematical Teaching. Mr. G. St. L. Carson read a paper on some unrealised possibilities in mathematical education, and there was a discussion on the introduction of the calculus, in which $\mathrm{Mr}$. C. V. Durell, Mr. A. W. Siddons, Dr. T. P. Nunn, and others took part.

Broadly stated, the papers threw light upon (I) the democratisation of mathematics; (2) the relation between the instrumental and the philosophical elements in mathematical teaching. Prof. Hobson's address makes clear what we wish to convey by (I), and we observed that the idea influenced most of the speakers. Prof. Perry and the Board of Education use the term "practical mathematics" in the sense of vocational mathematics, and Prof. Hobson had apparently the same idea in his references to "practical life." Where the president spoke of the "practical side" being overdeveloped he had in view laboratory exercises. By "instrumental" mathematics we mean the method of teaching which uses the utilitarian motive in order to lead the pupil to mathematical concepts. We put it that Prof. Hobson recognises the democratisation of mathematics as a welcome fact, believes that this justifies some, but not exclusive, use of the instrumental method, and lays stress on the necessity for combining with the latter considerable philosophical and deductive training. Mr. Godfrey told us that Italy had, more than any other country, continued to demand a philosophical treatment of geometry from young beginners, employing methods more rigorous than those of Euclid. Germany, on the other hand, had gone farther than any other nation in develop-

1 Continued from p. 394 .

NO. 2204, VOL. 88] 
ing the instrumental aspect. The Italians did not seem to be satisfied with their own results. The discussion on the calculus showed methods which had been successful in introducing this subject into schools (cf. Sir Joseph Thomson's laudatory remarks). The requirements of the physicist and engineer had been in view from beginning to end, but attention had been paid to the concepts of limits, differential coefficient, differential equation. In fact, mathematical masters in the larger schools were prepared to follow Prof. Perry in many of his reforms and extensions of their curricula, but part company with him when he asks them to eliminate philosophical considerations, as unsuited to boys. Mr. Carson went a stage further. He advocated a more philosophical treatment from the beginning of arithmetic, geometry, and algebra, in the order named, and would introduce pure mathematics-in the sense in which Bertrand Russell uses the term-to the older pupils. This he did because he believed that the modern theories of pure mathematics were destined to illumine our understanding of psychology, history, sociology, and economics, just as the older mathematics had thrown light on electricity, heat, light, and other physical sciences. He would teach mathematical philosophy as instrumental to human thought and social development, in that it shows the true relation between thought and experience.

\section{Progress of the Societies.}

At the business meeting it was reported that nearly all public schools are represented in the Science Masters' Association. The committee had been invited to assist the Army Council in connection with science examinations, and their advice had been utilised. The Oxford and Cambridge Joint Board had agreed to the request of the committee for extended time for practical chemistry. The General Medical Council had altered their regulations so as to admit a public school, under certain conditions, to "recognition as an institution where medical study may be begun."

The Mathematical Association has grown during the year, and now has 675 members and 200 associates, the increase of branch activity being worthy of remark. The Mathematical Gazette has been enlarged and made more useful to teachers, and the library is being made more accessible to members.

\section{Exhibition of Apparatus.}

There was a large and instructive display of apparatus in the common rooms of the London Day Training College, of which we are only able to give a few instances. Mr. D. Berridge provided a cheap, serviceable optical bench with vertical adjustments to the stands, while another felt want is supplied by the very handy electrolytic cell of the Rev. W. Burton. Mr. G. H. Martin's model volcanoes will be widely copied, and his dissociation model would be a useful adjunct to the college lecture-room. A carbon rheostat made by the Loretto boys appeared to be a serviceable instrument. We should like to see more evidence of boys' ingenuity and handicraft; its rarity suggests a weak point in the teaching, which it is quite possible is more apparent than real. A simple method of finding the surface-tension of a soap-film, shown by the Rev. S. A. McDowall, gave promise of considerable accuracy. Among the exhibits of business firms we noted more improvements and additions to apparatus of established repute than absolute novelties. Useful instruments for electrical and magnetic instruments, strong but cheap, were shown by Griffin and Sons, Philip Harris and Co., Becker and Co., Gambrell Bros., and others. We noticed a very good "wireless" set by Becker at ten guineas. Nalder Bros. have improved that originally excellent instrument the Ayrton-Mather universal shunt. Watson and Sons had a good display of microscopes, and their " $\mathrm{H}$ " stand offers more conveniences, combined with precision, than we have found in an extensive experience of Continental instruments. The laboratory fittings by Baird and Tatlock, the stills and ovens by Brown and Son, the lanterns by Reynolds and Branson, are well known, and are being constantly improved. Some gas-generators shown by Townson and Mercer are well suited to school use, and the NO. 2204 , VOL. 887 foot-bellows, without rubber, supplied by Gallenkamp and Co. will appeal to many. The requirements for laboratory mathematics are admirably met by G. Cussons, Ltd. and we believe that the school apparatus of the future will follow the lead given by this firm in making use of sets of apparatus with interchangeable parts attached to trulymade substantial standards. They show a hand-microtome which is really efficient and easy to use. As many science masters work in remote districts, they took the opportunity to inspect the well-chosen books exhibited by Messrs. Arnold, Bell, Cambridge University Press, Macmillan, Methuen, Oxford University Press, and University Tutorial Press. G. F. Daniell.

\section{BIRD-NOTES.}

I $N$ the second part of vol. ix. of the Transactions of the Norfolk and Norwich Naturalists' Society, Mr. J. H. Gurney records what is known with regard to the history of the stuffed specimen and egg of the great auk in the Norwich Museum. The egg, which is noteworthy on account of the well-preserved colouring of the markings, was presented to the museum in Igro by Mr. James Reeve on his retirement from the curatorship. It was bought by Mr. Reeve from Mr. J. H. Walter, by whose father it was purchased about 1850 from Dr. Pitman. Beyond this its history cannot be definitely traced, although the suggestion has been made that it originally came from the Hamburg dealer J. G. Brandt. The stuffed bird was presented to the museum in 1873 by Mrs. E. P. Clarke, daughter of $\mathrm{Mr}$. Edward Lombe, of Melton, near Norwich, to whom it previously belonged. Mr. Lombe bought it from Benjamin Leadbeater, the taxidermist, of Brewer Street, Golden Square, W.C., some time previous to 1822 ; but here its history ends. In spite of having probably been stuffed about seventy years ago, the plumage is still in fine condition.

In The Emu for October, I9II, the well-known ornithologist Mr. Sergius A. Buturlin gives a list of species of Australian birds which visit Siberia. The list includes no fewer than forty-eight species, of which, however, three are only occasional stragglers to the Far North. Of these some ten or eleven breed not only in Siberia, but likewise, although perhaps in slightly different forms, in Australia.

The Transactions of the Edinburgh Field Naturalists' and Microscopical Society for 1910-II (vol. vi., part iv.) contains a paper on bird-migration in the Solway district, communicated by the late Mr. Robert Service six months before his death. In one passage the author emphasised the fact that every British bird, except the grouse and perhaps one other species, is, to some extent at any rate, migratory. "All the individuals of such a species as, for example, the robin, shift their quarters a few degrees north or south at the migration seasons. It will thus happen that at the northernmost limit of the distribution of such a species no birds of that species will be found in winter, while similarly, at the southern limits of its range, no birds of the species will be found in winter."

Later, the opinion is expressed, on several grounds, that the returns from lighthouses relating to bird-migrations are based on misleading data, as birds are never low enough to strike the stations except when the weather is very dark or thick, or when they are driven down by strong gales.

The feature of the December (19ri) number of Witherby's British Birds is formed by three superb photographs of the black-throated diver, taken by Mr. O. G. Pike in the Outer Hebrides. The photographs were taken from a stone hut, built, with special precautions, near the nest. "The bird before me," writes the artist, "was absolutely unconscious of any danger, and it was really beautiful to watch her as she settled down upon her two eggs. At first she could not get comfortable, and I exposed a good many plates, but when she eventually settled it seemed impossible to move her.'

The damage inflicted on trees and timber by woodpeckers forms the subject of Bulletin No. 39 of the Biological Division of the U.S. Department of Agriculture. From an economic point of view the author, Mr. W. L. McAtee, divides the group into true woodpeckers, which are mainly beneficial, and sap-suckers, which are very injurious. 